\title{
PLASTIC COVERING, PLANTING DENSITY, AND PRUNNING IN THE PRODUCTION OF CAPE GOOSEBERRY (Physalis peruviana L.) IN SUBTROPICAL REGION ${ }^{1}$
}

\author{
PEDRO HENRIQUE ABREU MOURA ${ }^{2}$, GIVAGO COUTINHO ${ }^{3}$, RAFAEL PIO ${ }^{3 *}$, FLÁVIO GABRIEL BIANCHINI ${ }^{3}$, \\ PAULA NOGUEIRA CURI ${ }^{3}$
}

\begin{abstract}
Physalis peruviana L. is a perennial plant, but commonly referred as annual in commercial crops. The cultivation of this species might be successful in Brazilian subtropical areas with an adequate and planned management. The objective of the present study was to quantify the production of Physalis peruviana L. with or without plastic covering over plant canopies, using two planting densities, managing the number of stems, and pruning side stems. This study was divided in two experiments; the first experiment evaluated the effect of spacing between each plant and the use of plastic covering in fruit production. The second experiment investigated the effect of the number of productive stems and of pruning in fruit production. The experimental design used for both experiments was randomized blocks, in $2 \times 2$ factorial scheme, which contained 6 blocks and 10 plants per plot. The following were analyzed for both experiments: production variables, estimated production, number of fruits per plant, mean fruit mass, mean fruit length and diameter, and chlorophyll relative index. Plastic covering and number of stems did not influence fruit production. The $3.0 \times 0.5 \mathrm{~m}$ spacing without pruning side stems provided a larger production.
\end{abstract}

Keywords: Thickening. Small fruits. Productivity. Plasticulture.

\section{COBERTURA PLÁSTICA, DENSIDAde de PLANTIO E PODA NA PRODUÇÃO DE FISÁLIS (Physalis peruviana L.) EM REGIÃO SUBTROPICAL}

\begin{abstract}
RESUMO - A Physalis peruviana L. é uma planta perene, mas usualmente tratada como anual em plantios comerciais. Com um manejo adequado e planejado, o cultivo pode ter sucesso nas zonas subtropicais brasileiras. Objetivou-se neste trabalho, quantificar a produção de Physalis peruviana L. através da utilização ou não de cobertura plástica sobre o dossel das plantas, do uso de duas densidades de plantio, do manejo no número de hastes e utilização de poda das hastes laterais. $\mathrm{O}$ trabalho foi dividido em dois experimentos, onde no primeiro experimento avaliou-se o efeito do espaçamento entre plantas e uso de cobertura plástica na produção de frutos. O segundo experimento constituiu do efeito do número de hastes produtivas e uso da poda na produção de frutos. $\mathrm{O}$ delineamento experimental adotado, para ambos os experimentos foi blocos ao acaso, em esquema fatorial 2 x 2, contendo 6 blocos e 10 plantas por parcela. Para ambos os experimentos foram analisadas as variáveis produção, produtividade estimada, número de frutos por planta, massa média dos frutos, comprimento e diâmetro médio dos frutos e índice relativo de clorofila. A cobertura plástica e o número de hastes não influenciaram na produção dos frutos. O espaçamento de 3,0 x 0,5 m sem o uso da poda das hastes laterais proporcionaram a maior produção.
\end{abstract}

Palavras-chave: Adensamento. Pequenas frutas. Produtividade. Plasticultura.

\footnotetext{
*Author for corresponding

${ }^{1}$ Received for publication in 06/15/2015; Accepted in 01/22/2016.

Extracted from the first author's doctoral thesis.

${ }^{2}$ Empresa de Pesquisa Agropecuária de Minas Gerais Maria da Fé, MG, Brazil; pedrohamoura@yahoo.com.br.

${ }^{3}$ Department of Agricultural, Universidade Federal de Lavras, Lavras, MG, Brazil; givago_agro@hotmail.com, rafaelpio@dag.ufla.br, fgbianchini@yahoo.com.br, paulanogueiracuri@yahoo.com.br.
} 


\section{INTRODUCTION}

Physalis peruviana L. is a species of the Solanaceae family, a perennial plant but usually referred as annual in commercial crops. This plant cultivation might stay in production for up to two years with an adequate management and according to the predominant region and climate. However, after the second year, there is a decrease in fruit production and quality (MUNIZ et al., 2011).

Plants can reach up to 2 meters high, needing a supporting and training system since it has an herbaceous and decumbent stem. Their roots are axial with several ramifications. The leaves are simple and oval shaped, presenting hairiness (GONÇALVES et al., 2012).

Physalis peruviana L. recently entered the small fruits ranking and has presented a large potential for the national and international markets, with a high value as fresh fruit, attracting consumers due to its exotic flavor and numerous nutritional benefits (RODRIGUES et al., 2014).

Physalis peruviana L. is considered a fruit tree of simple cultivation. Large part of its culture practices is carried out based on the tomato plant cultivation (LIMA et al., 2009; IANCKIEVICZ et al., 2013). Physalis peruviana L. has a potential to be produced in subtropical areas, similarly to small fruits like blackberries and raspberries, since there are similarities in their climatic demands and cultivation techniques such as farming practices and harvesting (MOURA et al., 2012, TIBERTI et al., 2015).

Pruning is a technique used for several crops, being that plants present different degrees of tolerance to this management. For instance, regarding blackberry bushes, an adequate management of pruning is essential for a good productivity (CAMPAGNOLO; PIO, 2012). Segantini et al. (2014) conducted an early winter pruning in "Tupy" blackberry, which was cultivated in the region of São Manuel, in the state of São Paulo, and were able to harvest it outside of the traditional harvesting season. It is possible that studies on Physalis peruviana L. pruning might bring positive effects in the cultivation of this species.

Another important factor to be considered is a better use of the area where this species is explored by the means of increasing the production per area. Thus, it is expected to obtain an increase in the orchards productivity when decreasing the spacing between the plants. Curi et al. (2014) found some advantages in relation to the quality of raspberries that were produced in thickened spacing in Southern Minas Gerais state.

Fruit trees cultivation under plastic covering is a measure that might benefit the quality of fruits as well as reduce the use of chemicals in the orchard (PEDRO JÚNIOR; HERNANDES; ROLIM, 2011, CURI et al., 2014, MARO et al., 2014); in addition to preventing hail detrimental effects and excessive wind (HERNANDES et al., 2013). Based on Comiran et al. (2012), this measure has already been established in vineyards to prevent the effects of excessive rainfall over the plant canopy, especially during fruit maturation, helping to maintain the quality of grapes.

Therefore, the objective of the present study was to quantify the production of cape gooseberry (Physalis peruviana L.) in subtropical region with and without plastic covering, using two planting densities, managing the number of stems, and pruning side stems.

\section{MATERIAL AND METHODS}

This study was divided in two experiments of sequential design. Both experiments were conducted in the Horticulture Sector at the Federal University of Lavras (Universidade Federal de Lavras UFLA), in the city of Lavras, southern region of the state of Minas Gerais, Brazil, from 2012 through 2014. The municipality is located at $21^{\circ} 14^{\prime} \mathrm{S}$ and $45^{\circ} 00^{\prime} \mathrm{W}$, with an average altitude of 918 meters. According to the Köppen classification, the region's climate is $\mathrm{Cwb}$ (mesothermal or temperate highland tropical climate), with dry winters and humid summers (KOTTEK et al., 2006).

Physalis peruviana L. seedlings were produced from seeds. The seeds were extracted from mature fruits that were harvested at UFLA's orchard and seeded on expanded polystyrene trays of 128 cells with Biomix ${ }^{\circledR}$ commercial substrate, in a protected environment. Seedlings began to emerge in 15 to 20 days and were transplanted to an open field 60 days after they had emerged, when they were 15 $\mathrm{cm}$ high and presented 3 to 4 definite leaves (MUNIZ et al., 2015).

The soil $\mathrm{pH}$ correction of both experiments was carried out 60 days prior to transplanting the seedlings, based on the soil correction needs indicated by the soil analysis. The fertilizing recommendation was carried out according to the tomato plant cultivation practices, with $10 \mathrm{t} \mathrm{ha}^{-1}$ productivity expectation (MUNIZ et al., 2015). All plants were irrigated with the use of drippers spaced at every $30 \mathrm{~cm}$, with a flow rate of 1.7 liters per hour in each dripper (CURI et al., 2014).

Same variables were used in both experiments by considering harvesting periods in each planting season. Harvesting begins five months after transplanting seedlings and once it has begun it must be continuous and weekly, with an approximate duration of six months (LIMA et al., 2013). The fruits present an orange color when they are mature; however, the harvesting is carried out when the bud presents a golden yellow color. The bud color change matches the fruit maturation period, thus defining the point of harvest (RUFATO et al., 2008). 
The following variables were evaluated through the harvesting that was carried out twice a week: production $\left(\mathrm{g}\right.$ plant $\left.{ }^{-1}\right)$, estimated productivity $\left(\mathrm{t} \mathrm{ha} \mathrm{a}^{-1}\right)$, number of fruits per plant, and mean fruit mass $(\mathrm{g})$. Fruits were counted, and the mass was obtained with the assistance of a digital semianalytical scale, model BL3200S. At the end of the cycle, all fruits were summed up and all masses were registered in order to determine the production per plant and to estimate the productivity, considering the number of plants per hectare in each spacing. At each harvesting, ten fruits of each plot were removed to determine the mean length and diameter, using a digital pachymeter, model LEE TOOLS-684132. These physical characteristics were evaluated in the Laboratory of Horticulture Sector at UFLA.

During full production periods, indirect measurements of chlorophyll were determined using a portable chlorophyll meter, model SPAD-502. Readings were carried out in the approximate center of three Physalis peruviana L. leaves of each plot, always using a middle third mature leaf that was not shaded by other leaves, and in only one side of the vein (set distance by the device depth regulator), based on what was conducted by Curi et al. (2015a) in other small fruits.

The experimental design used was in randomized blocks, in $2 \times 2$ factorial scheme, with six blocks and ten plants per plot. Data were subjected to variance analysis and means were compared by the Tukey test, at 5\% level of error probability (FERREIRA, 2011).

First Experiment: Spacing between plants and the use of plastic covering in the production of Physalis peruviana $\mathrm{L}$.

The experiment was conducted from April of 2012 through March of 2013. Plants were transplanted to an open field in May of 2012, using two planting densities: $3.0 \mathrm{~m} \times 1.0 \mathrm{~m}$ (density of 3.333 plants per hectare) and $3.0 \mathrm{~m} \times 0.5 \mathrm{~m}$ (density of 6.667 plants per hectare) (RUFATO et al., 2012, MUNIZ et al., 2014).

Plants were trained on espaliers that were constituted by two eucalyptus posts, $1.6 \mathrm{~m}$ high, spaced at $90 \mathrm{~cm}$, with parallel flat wires located at $1.5 \mathrm{~m}$ from the soil, being that the plants training system and farming practices were carried out based on Muniz et al. (2011) recommendations.

Factors consisted of two planting densities ( 0.5 and $1.0 \mathrm{~m}$ between the plants) with $3.0 \mathrm{~m}$ between the lines, with the use of or without plastic covering over the plant canopy. Plants were covered with a milky PEBD plastic, $150 \mu \mathrm{m}$ thick, in the treatments that a plastic covering was used. This covering was installed over metal threads and galvanized iron arches, $1.4 \mathrm{~m}$ wide, disposed over plants canopy every $2.5 \mathrm{~m}$, and the arches were, in turn, fixed on the eucalyptus posts structure The highest point of the plastic covering was $40 \mathrm{~cm}$ high, in relation to the edge of Physalis peruviana L plants.

The global radiation intensity $\left(\mathrm{W} \mathrm{m}^{-2}\right)$ was measured in the spring (October/2012) and in the summer (December/2013), between 6:30h and $17: 30 \mathrm{~h}$, through a pyrometer attached to a data logger (LI-1400 LI-COR). These pyrometers were installed above the plant canopy, regardless of spacing, being that in the covered treatments, they were placed below the plastic covering.

During the experiment, from August of 2012 and March of 2013, minimum and maximum temperatures and the relative humidity were measured in the experimental area with the assistance of a digital thermo-hygrometer, model 7666.02.0.00, over the Physalis peruviana L. plants canopy that were cultivated at open skies, and between the plant canopy and the plastic covering of Physalis peruviana L. that were cultivated underneath the covering.

\section{Second experiment: Number of productive stems and pruning in the production of Physalis peruviana $\mathrm{L}$.}

The experiment was conducted from May of 2013 to February of 2014. The transplanting to open field was carried out in June of 2013, using $3.0 \mathrm{~m} \mathrm{x}$ $0.5 \mathrm{~m}$ planting density (density of 6,667 plants per hectare) in the area where podiums constituted of two eucalyptus posts were installed at $1.6 \mathrm{~m}$ high, spaced at $90 \mathrm{~cm}$, with parallel flat wires located at $1.5 \mathrm{~m}$ from the soil, to conduct the culture (MUNIZ et al., 2011)

Plants were trained with 4 and 2 stems through sprouting of surplus branches, from August to September of 2013.

Factors consisted of the number of stems that were trained to production (two or four), and pruning to reduce plants side stems or the absence of pruning.

Pruning was carried out in January of 2014 in those plants that were trained with two and four main stems. This procedure decreased the side stems and maintained plants with two buds from the main branch of the Physalis peruviana L. plant.

\section{RESULTS AND DISCUSSION}

First experiment: Spacing between plants and the use of plastic covering in the production of Physalis peruviana $\mathrm{L}$.

There was not a significant interaction among the factors studied, being that only productivity presented a significant difference, when increasing planting density provided a greater number of fruits without altering the fruits' size (Table 1).

Plastic covering, Planting density 
Table 1. Production (P), estimated productivity (EP), number of fruits per plant (NFP), mean fruit mass (MFM), mean fruit length (MFL), mean fruit diameter (MFD), and chlorophyll relative index (CRI) of cape gooseberry (Physalis peruviana L.) that was cultivated with and without plastic covering over plants canopy and in two plating spacing.

\begin{tabular}{crrrrr}
\hline Variable analyzed & \multicolumn{2}{c}{ Plastic covering } & \multicolumn{2}{c}{ Planting } & \multirow{2}{*}{ C.V. (\%) } \\
\cline { 2 - 4 } & \multicolumn{1}{c}{ With } & Without & $3.0 \times 0.5 \mathrm{~m}$ & $3.0 \times 1.0 \mathrm{~m}$ & \\
\cline { 2 - 5 } & $1674.80 \mathrm{a}^{*}$ & $1751.00 \mathrm{a}$ & $1635.90 \mathrm{a}$ & $1789.80 \mathrm{a}$ & 15.94 \\
P $\left(\right.$ g plant $\left.^{-1}\right)$ & $8.33 \mathrm{a}$ & $8.54 \mathrm{a}$ & $10.91 \mathrm{a}$ & $5.97 \mathrm{~b}$ & 19.87 \\
${\text { PP }\left(\mathrm{t} \mathrm{ha}^{-1}\right)}_{\text {NFP }}$ & $460.30 \mathrm{a}$ & $508.70 \mathrm{a}$ & $470.30 \mathrm{a}$ & $498.70 \mathrm{a}$ & 16.52 \\
MFM (g) & $2.50 \mathrm{a}$ & $2.50 \mathrm{a}$ & $2.50 \mathrm{a}$ & $2.50 \mathrm{a}$ & 12.20 \\
MFL (mm) & $16.40 \mathrm{a}$ & $16.50 \mathrm{a}$ & $16.40 \mathrm{a}$ & $16.50 \mathrm{a}$ & 2.73 \\
MFD (mm) & $16.20 \mathrm{a}$ & $16.60 \mathrm{a}$ & $16.50 \mathrm{a}$ & $16.40 \mathrm{a}$ & 3.35 \\
CRI & $49.00 \mathrm{a}$ & $50.90 \mathrm{a}$ & $49.90 \mathrm{a}$ & $50.00 \mathrm{a}$ & 4.52 \\
\hline
\end{tabular}

${ }^{*}$ Means that are followed by the same letter in the row are not different between each other, by the Tukey test, at $5 \%$ error probability.

In the $3.0 \times 1.0 \mathrm{~m}$ spacing, plants presented the least estimated productivity, $5.97 \mathrm{t} \mathrm{ha}^{-1}$, a similar result to the one obtained by Muniz et al. (2011), whom reported an estimated productivity of $6 \mathrm{tha}^{-1}$ in the plateau region of the state of Santa Catarina, Brazil, where the same spacing between plants as well as the same stem training system in " $\mathrm{X}$ " were used. Results were higher when the spacing was decreased to $3.0 \times 0.5 \mathrm{~m}$ and the estimated productivity was increased to $10.91 \mathrm{t} \mathrm{ha}^{-1}$. This value is below the mean productivity of the main producing countries of Physalis peruviana L. in South America: Colombia and Ecuador with 14.5 and $13.6 \mathrm{t} \mathrm{ha}^{-1}$, respectively (FISCHER; ALMANZA -MERCHÁN; MIRANDA, 2014). Curi et al., 2015b also obtained higher productivity in thickened spacing for raspberries, which are small fruits similarly to Physalis peruviana L.

It is known that the crops productivity is influenced by the availability of solar radiation (RUFATO et al., 2008). Data obtained by global radiation through pyrometers, indicate that radiation values obtained in the spring and in the summer were higher for the treatment without the plastic covering, in relation to the treatment with the covering. This difference might be explained due to the reducing effect exercised by the plastic covering over the global radiation that is able to absorb and reflect the incident radiation (ANDRIOLO, 1999). Nevertheless, results show that plastic covering did not have an influence either in the plants production or in the estimated productivity (Table 1).

During the spring, the radiation intensity varied from 33.4 to $1006.1 \mathrm{~W} \mathrm{~m}^{-2}$ for the treatment without the covering, and of 35.1 to $954.1 \mathrm{~W} \mathrm{~m}^{-2}$ for the treatment with the covering. In the summer, in turn, both treatments had an increase of radiation intensity, oscillating from 75.3 to $1151.9 \mathrm{~W} \mathrm{~m}^{-2}$ for the treatment without the covering, and from 65.4 to $1019.9 \mathrm{~W} \mathrm{~m}^{-2}$ for the treatment with the covering. It was observed that certain radiation values decrease abruptly and soon after returning to their standard arrangement. This factor may be associated with the formation of clouds at the time (Figure 1).

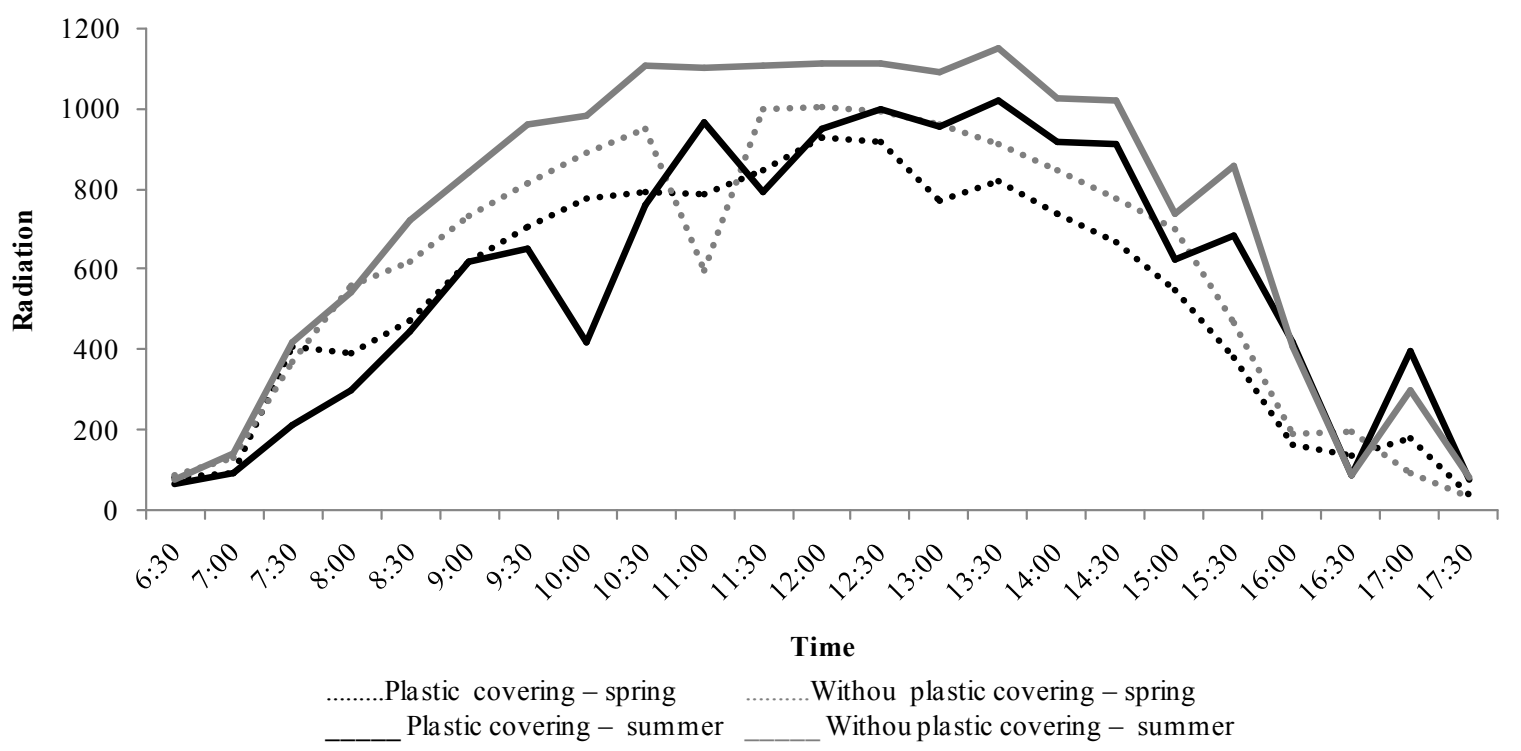

Figure 1. Radiation quantification in cape gooseberry (Physalis peruviana L.), with and without plastic covering over the plant canopy, which was measured during the day, in two seasons (spring/2012 and summer/2013). 
The temperature values that were collected from August of 2012 to March of 2013 did not show a significant difference between the treatments (Figure 2). The minimum and maximum temperatures in the treatment without the covering were $10.9^{\circ} \mathrm{C}$ and $36.4{ }^{\circ} \mathrm{C}$, and $11.7^{\circ} \mathrm{C}$ and $39.7^{\circ} \mathrm{C}$ in the treatment with the covering, respectively. Based on Rufato et al. (2008), species of the Physalis L. genus are susceptible to extreme temperatures. However, high temperatures may affect blooming and fruiting; in turn, low temperatures may impede plants from flourishing.

The mean relative humidity also collected from August of 2012 through March of 2013, was higher in the treatment without plastic covering $(64.2 \%)$, varying from 54 to $71 \%$ (Figure $2 \mathrm{~A}$ ). In the treatment with covering, in turn, the mean relative humidity was lower (54\%), varying from $45 \%$ to $62 \%$ (Figure 2B). It was observed that for both treatments, the highest values were shown in the rainy season (October to March). Based on Rufato et al. (2008), the mean relative humidity for Physalis L. cultivation must be from 70 to $80 \%$, which are close values to the ones found in the treatment without covering. It is important to note that excessive humidity may be favorable to the emergence of diseases and impair pollination, which might cause plants with a yellowish color and fewer leaves.
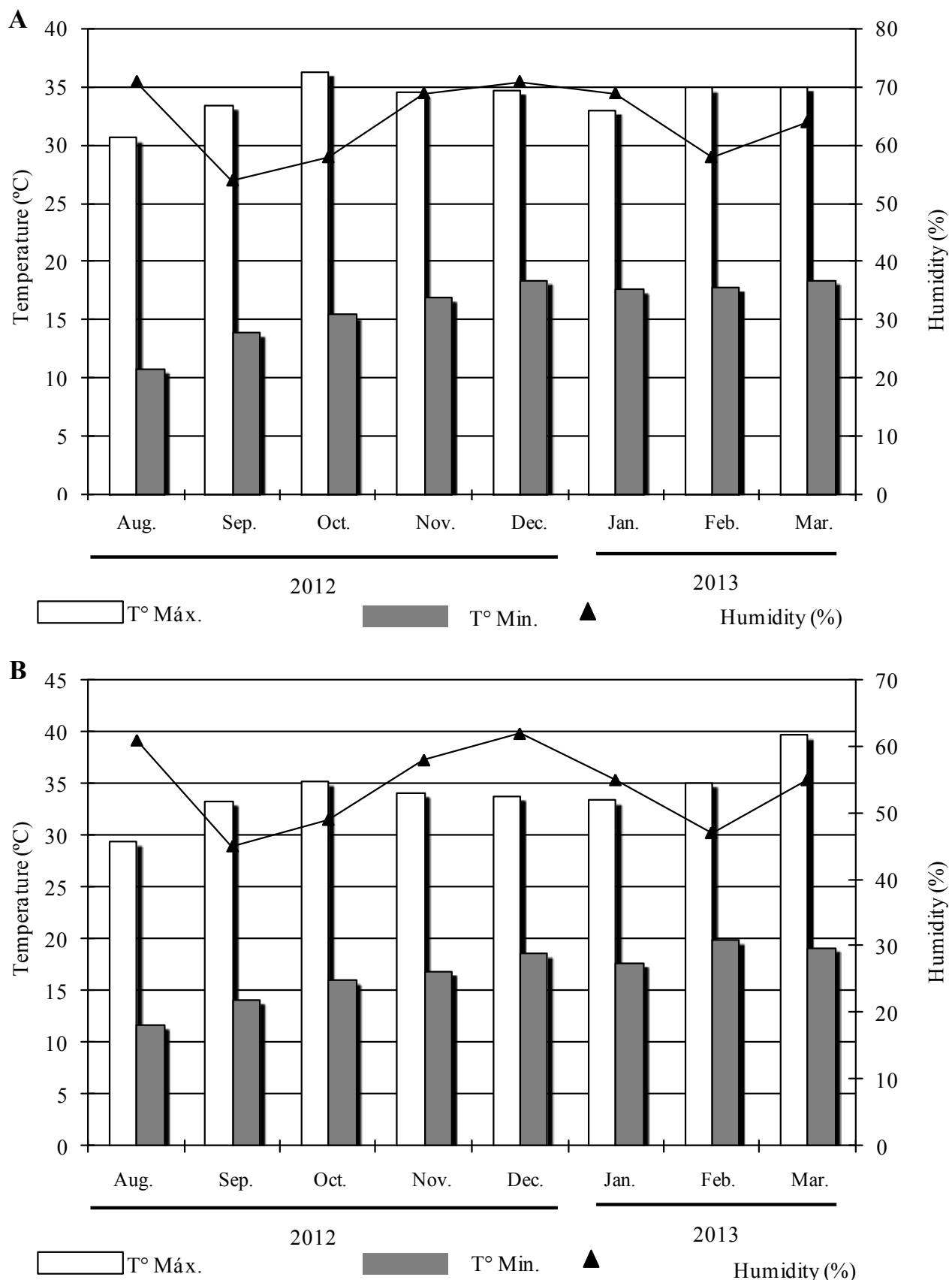

Figure 2. Maximum and minimum temperatures and relative humidity, from August/2012 to March/2013 in cape gooseberry (Physalis peruviana L.) that were cultivated without covering (A) and with plastic covering (B) over plants canopy.

Rev. Caatinga, Mossoró, v. 29, n. 2, p. 367 - 374, abr. - jun., 2016 
The chlorophyll relative index did not show a significant difference between the treatments (Table 1). Curi et al. (2015b), when studying another small fruit, the 'Batum' raspberry plant, did not observe statistical differences either in chlorophyll indirect measurements for plants that were either cultivated with and without plastic covering over the canopy or in two planting densities. Further evaluations with a larger sample and including all four seasons are needed, in order to obtain more solid results about the characteristics described previously, since there is a lack of information in the literature on Physalis peruviana $\mathrm{L}$.

Based on the results, the highest planting density was the treatment that obtained the highest productivity. When comparing the treatments with and without plastic covering, there was no statistical difference for productivity; therefore, it is not necessary to invest in installing plastic covering over the plants.

\section{Second experiment: Number of productive stems and pruning in the production of Physalis peruviana $\mathrm{L}$.}

Regarding all variables analyzed, there was no significant interaction between the number of stems trained to production (two and four) and pruning. The number of stems did not show significant differences for the variables that were analyzed: production $\left(\mathrm{g}\right.$ planta $\left.{ }^{-1}\right)$, productivity ( $\mathrm{t}$ ha ${ }^{1}$ ), and number of fruits per plant. In plants with a larger number of stems the production per stem was lower. For this reason, plants with two and four stems presented similar productions (Table 2). Muniz et al. (2011) in a study carried out in the plateau of Santa Catarina state, reported the effect of culture training system over fruits quality and productivity. This difference may be associated with the region climatic and soil conditions in the development of Physalis peruviana L. plants. Another factor that might have influenced these variables may be associated with the planting period. Betemps et al. (2014) reported that Physalis peruviana L. sowing that is carried out in the beginning of September results in plants with a higher vegetative growth and larger number of fruits, and the characteristics of growth and production are similar to this species main cultivation regions.

Table 2. Production (P), estimated productivity (EP), number of fruits per plant (NFP), mean fruit mass (MFM), mean fruit length (MFL), mean fruit diameter (MFD), and chlorophyll relative index (CRI) of cape gooseberry (Physalis peruviana $\mathrm{L}$.) that was cultivated with two types of stems for the training, and with the use of pruning to reduce the side stems.

\begin{tabular}{crrrrr}
\hline Variable analyzed & \multicolumn{2}{c}{ Number of stems } & \multicolumn{2}{c}{ Stems reduction pruning } & C.V. (\%) \\
\cline { 2 - 4 } & \multicolumn{1}{c}{2} & 4 & With & Without & \\
\hline P $\left(\right.$ g plant $\left.^{-1}\right)$ & $1867.14 \mathrm{a}^{*}$ & $1839.44 \mathrm{a}$ & $1615.92 \mathrm{~b}$ & $2090.62 \mathrm{a}$ & 12.12 \\
EP $\left(\mathrm{t} \mathrm{ha}^{-1}\right)$ & $6.22 \mathrm{a}$ & $6.13 \mathrm{a}$ & $5.39 \mathrm{~b}$ & $6.97 \mathrm{a}$ & 12.10 \\
NFP & $459.66 \mathrm{a}$ & $482.66 \mathrm{a}$ & $361.94 \mathrm{~b}$ & $560.60 \mathrm{a}$ & 11.04 \\
MFM (g) & $3.44 \mathrm{a}$ & $3.27 \mathrm{~b}$ & $3.01 \mathrm{~b}$ & $3.70 \mathrm{a}$ & 4.63 \\
MFL (mm) & $20.15 \mathrm{a}$ & $19.56 \mathrm{~b}$ & $20.15 \mathrm{a}$ & $19.56 \mathrm{~b}$ & 2.91 \\
MFD (mm) & & & & \\
CRI & $20.12 \mathrm{a}$ & $20.25 \mathrm{a}$ & $20.53 \mathrm{a}$ & $19.84 \mathrm{a}$ & 4.41 \\
& $50.13 \mathrm{a}$ & $52.40 \mathrm{a}$ & $52.18 \mathrm{a}$ & $50.35 \mathrm{a}$ & 4.78 \\
\hline
\end{tabular}

*Means that are followed by the same letter in the row are not different between each other, by the Tukey test, at $5 \%$ error probability.

The production of $\left(\mathrm{g}\right.$ planta $\left.^{-1}\right)$ Physalis peruviana $\mathrm{L}$. for the treatments with and without pruning was 1615.92 and 2090.62, respectively, showing that pruning under the present study conditions promoted a decrease of production per plant. These values are higher than the conditions in greenhouse cultivation, as reported by Rodrigues et al. (2013), in which a study under greenhouse conditions reached a production of $215 \mathrm{~g} \mathrm{plant}^{-1}$.

The treatment in which pruning was not carried out, presented the best productivity
(6.97 $\mathrm{t} \mathrm{ha}^{-1}$ ) in relation to plants that underwent pruning of productive stems; these values are among means found by Lima et al. (2010), whom when evaluating different methods of Physalis peruviana L. plants during the productive cycle found values between 4.53 and $14.36 \mathrm{t} \mathrm{ha}^{-1}$.

Regarding the mean fruit mass $(\mathrm{g})$ variable, there was a significant difference for the number of stems as well as for pruning or without pruning, being that the highest mean masses were $3.44 \mathrm{~g}$ for plants trained with two stems and $3.70 \mathrm{~g}$ in the 
treatment in which pruning was not carried out to reduce the stems. These values agree with those reported by Lima et al. (2012), whom investigated the evaluation of Physalis peruviana L. fruits quality throughout the harvesting season, when they found mean fruit mass values between 3.0 and $5.0 \mathrm{~g}$. The highest means found in plants trained with two stems in relation to plants maintained with four stems might be associated with Physalis peruviana L. fruiting dynamics. This species has a long harvesting period and after peak production, a decrease in the number of fruits occur as a function of the change of source/sink relation (RUFATO et al., 2008), in which the practice of maintaining two stems may have possibly affected this relation.

Regarding the parameters of diameter and length, there was a significant difference only for the length, presenting a $20.15 \mathrm{~mm}$ mean for plants that were kept with two stems as well as for plants that underwent pruning to reduce side stems. Possibly, the fewest number of stems and stems pruning resulted in a stronger source/sink relation, which provided a higher growth of these plants fruits. This result is higher than the one described by Silva et al. (2013), whom when evaluating Physalis peruviana L. culture performance under the conditions in Southern Minas Gerais state found an $18.50 \mathrm{~mm}$ mean value for fruit length.

The chlorophyll relative index did not present significant differences for any of the variables analyzed; further experiments on the number of samples and harvesting period are needed.

\section{CONCLUSIONS}

The use of plastic covering does not influence any variables that were analyzed.

The $3.0 \times 0.5 \mathrm{~m}$ spacing allows higher productivity of cape gooseberry (Physalis peruviana L.) fruits.

Plants trained with two stems promote higher mean fruit mass values and fruit length.

In subtropical region, it is not necessary to reduce the number of cape gooseberry (Physalis peruviana L.) stems.

\section{ACKNOWLEDGMENTS}

To the Coordenação de Aperfeiçoamento de Pessoal de Nível Superior (CAPES), Conselho Nacional de Desenvolvimento Científico e Tecnológico (CNPq), and Fundação de Pesquisa do Estado de Minas Gerais (FAPEMIG) for the financial support in the development of the present study.

\section{REFERENCES}

ANDRIOLO, J. L. Fisiologia das culturas protegidas. Santa Maria, RS: UFSM, 1999. 142 p.

BETEMPS, D. L. et al. Época de semeadura, fenologia e crescimento de plantas de fisális no sul do Brasil. Revista Brasileira de Fruticultura, Jaboticabal, v. 36, n. 1, p. 179-185, 2014.

CAMPAGNOLO, M. A.; PIO, R. Poda drástica para a produção da amora-preta em regiões subtropicais. Pesquisa Agropecuária Brasileira, Brasília, v. 47, n. 7, p. 934-938, 2012.

COMIRAN, F. et al. Microclima e produção de videiras 'Niágara Rosada' em cultivo orgânico sob cobertura plástica. Revista Brasileira de Fruticultura, Jaboticabal, v. 34, n. 1, p. 152-159, 2012

CURI, P. N. et al. Produção de amora-preta e amoravermelha em Lavras - MG. Ciência Rural, Santa Maria, v. 45, n. 8, p. 1368-1374, 2015a.

CURI, P. N. et al. Produtividade e qualidade da framboeseira 'Batum' cultivada sob cobertura plástica e dois espaçamentos em região subtropical. Ciência Rural, Santa Maria, v. 45, n. 11, p. 19942000, 2015b.

CURI, P. N. et al. Qualidade de framboesas sem cobertura ou cobertas sobre o dossel e em diferentes espaçamentos. Revista Brasileira de Fruticultura, Jaboticabal, v. 36, n. 1, p. 199-205, 2014.

FERREIRA, D. F. Sisvar: a computer statistic alanalysis system. Ciência e Agrotecnologia, Lavras, v. 35, n. 6, p. 1039-1042, 2011.

FISCHER， G.; ALMANZA-MERCHÁN， P. J.; MIRANDA, D. Importancia y cultivo de la uchuva (Physalis peruviana L.). Revista Brasileira de Fruticultura, Jaboticabal, v. 36, n. 1, p. 1-15, 2014.

GONÇALVES, E. D. et al. Aspectos técnicos do cultivo de fisális para o Sul de Minas. Belo Horizonte: EPAMIG, 2012. 6 p. (Circular Técnica, 162).

HERNANDES, J. L. et al. Comportamento produtivo da videira 'Niagara Rosada' em diferentes sistemas de condução, com e sem cobertura plástica, durante as safras de inverno e de verão. Revista Brasileira de Fruticultura, Jaboticabal, v. 35, n. 1, p. 123-130, 2013.

IANCKIEVICZ, A. et al. Produção e desenvolvimento da cultura de Physalis L. submetida 
a diferentes níveis de condutividade elétrica da solução nutritiva. Ciência Rural, Santa Maria, v. 43, n. 3, p. 438-444, 2013.

KOTTEK, M. et al. World map of the KöppenGeiger climate classification updated. Meteorologische Zeitschrift, Berlin, v. 15, n. 3, p. 259-263, 2006.

LIMA, C. S. M. et al. Avaliação física, química e fitoquímica de frutos de Physalis, ao longo do período de colheita. Revista Brasileira de Fruticultura, Jaboticabal, v. 34, n. 4, p. 1004-1012, 2012.

LIMA, C. S. M. et al. Características físico-químicas de Physalis em diferentes colorações do cálice e sistemas de condução. Revista Brasileira de Fruticultura, Jaboticabal, v. 31, n. 4, p. 1060-1068, 2009.

LIMA, C. S. M. et al. Qualidade pós-colheita de Physalis sob temperatura ambiente e refrigeração. Revista Ceres, Viçosa, v. 60, n. 3, p. 311-317, 2013.

LIMA, C. S. M. et al. Sistemas de tutoramento e épocas de transplante de Physalis. Ciência Rural, Santa Maria, v. 40, n. 12, p. 2472-2479, 2010.

MARO, L. A. C. et al. Environmental and genetic variation in the post-harvest quality of raspberries in subtropical areas in Brazil. Acta Scientiarum. Agronomy, Maringá, v. 36, n. 3, p. 323-328, 2014.

MOURA, P. H. A. et al. Fenologia e produção de cultivares de framboeseiras em regiões subtropicais no Brasil. Pesquisa Agropecuária Brasileira, Brasília, v. 47, n. 12, p. 1714-1721, 2012.

MUNIZ, J. et al. Crescimento vegetativo e potencial produtivo de fisális. Revista de Ciências Agroveterinárias, Lages, v. 14, n. 1, p. 15-23, 2015.

MUNIZ, J. et al. General aspects of physalis cultivation. Ciência Rural, Santa Maria, v. 44, n. 6, p. 964-970, 2014.

MUNIZ, J. et al. Sistemas de condução para o cultivo de Physalis no planalto catarinense. Revista Brasileira de Fruticultura, Jaboticabal, v. 33, n. 3, p. 830-838, 2011.

PEDRO JÚNIOR, M. J.; HERNANDES, J. L.; ROLIM, G. S. Sistema de condução em Y com e sem cobertura plástica: microclima, produção, qualidade do cacho e ocorrência de doenças fúngicas na videira 'Niagara Rosada'. Bragantia, Campinas, v. 70, n. 1, p. 228-233, 2011.

RODRIGUES, F. A. et al. Caracterização fenológica e produtiva de Physalis peruviana cultivada em casa de vegetação. Biosciense Journal, Uberlândia, v. 29, n. 6, p. 1771-1777, 2013.

RODRIGUES, F. A. et al. Caracterização física, química e físico-química de physalis cultivada em casa de vegetação. Ciência Rural, Santa Maria, v. 44, n. 8, p. 1411-1414, 2014.

RUFATO, L. et al. Aspectos técnicos da cultura da fisalis. Informe Agropecuário, Belo Horizonte, v. 33, n. 268, p. 69-83, 2012.

RUFATO, L. et al. Aspectos técnicos da cultura da fisalis. Lages: CAV/UDESC; Pelotas: UFPel, 2008. $100 \mathrm{p}$.

SEGANTINI, D. M. et al. Exigência térmica e produtividade da amoreira-preta em função das épocas de poda. Revista Brasileira de Fruticultura, Jaboticabal, v. 36, n. 3, p. 568-595, 2014.

SILVA, D. F. et al. Conservação pós-colheita de fisális e desempenho produtivo em condições edafoclimáticas de Minas Gerais. Revista Ceres, Viçosa, v. 60, n. 6, p. 826-832, 2013

TIBERTI, A. S. et al. Armazenamento a frio e aplicação de reguladores vegetais no enraizamento de estacas radiculares e caulinares de framboeseira. Ciência Rural, Santa Maria, v. 45, n. 8, p. 1445 $1450,2015$. 